\title{
Altered Transcriptional Regulation of Phosphoenolpyruvate Carboxykinase in Rats Following Endotoxin Treatment
}

\author{
Molly Hill and Roderick McCallum \\ Department of Microbiology and Immunology, University of Oklahoma Health Sciences Center, Oklahoma City, Oklahoma 73190
}

\begin{abstract}
The molecular mechanism involved in altered regulation of the rate-limiting enzyme in hepatic gluconeogenesis, phosphoenolpyruvate carboxykinase (PEPCK), during endotoxemia is not completely understood. We examined, therefore, the effect of a nonlethal dose of Escherichia coli endotoxin on PEPCK gene expression in fasted rats. $5 \mathrm{~h}$ after endotoxin treatment, the PEPCK transcription rate and the amount of $m R_{N A}{ }^{\text {PEPCK }}$ were significantly decreased at a time when the insulin/glucagon (I/ G) molar ratio and plasma corticosterone levels were significantly increased. Similar results were observed in a time course study, in which altered CAMP induction of PEPCK gene expression paralleled changes in the I/G molar ratio. In diabetic rats treated with endotoxin, PEPCK gene expression was decreased in the absence, however, of an increased $I / G$ molar ratio. This finding indicates that other factors, such as inflammatory mediators or cytokines, alter PEPCK gene transcription during endotoxemia. IL-6, a putative mediator of endotoxin action in the liver, had no effect on PEPCK gene expression in fasted rats, but did decrease CAMP induction of PEPCK gene expression. These results indicate that, during endotoxemia, regulation of PEPCK gene expression is influenced by inflammatory mediators in addition to the classical endocrine hormones. IL-6, however, does not appear to be involved directly in the altered regulation of the PEPCK gene during endotoxemia. (J. Clin. Invest. 1991. 88:811-816.) Key words: insulin • glucagon • corticosterone • diabetic • interleukin 6
\end{abstract}

\section{Introduction}

Acute bacterial infections and a serious sequela, septic shock, remain significant health problems despite appropriate antimicrobial and supportive therapies. Septic or endotoxic shock is a complex syndrome characterized by hypotension, poor organ perfusion, and severe systemic metabolic derangements, particularly hypoglycemia. Hypoglycemia results from increased peripheral utilization of glucose, rapid depletion of liver glycogen, and depressed hepatic gluconeogenesis (1). It is well established

A portion of this work was presented at the First International Endotoxin Congress in San Diego on 9-12 May 1990.

Address correspondence and reprint requests to Dr. Molly Reid Hill, Department of Microbiology and Immunology, University of Oklahoma Health Sciences Center, P.O. Box 26901, Oklahoma City, OK 73190. 1991.

Received for publication 20 March 1991 and in revised form 29 May

J. Clin. Invest.

(C) The American Society for Clinical Investigation, Inc.

0021-9738/91/09/0811/06 \$2.00

Volume 88, September 1991, 811-816 that endotoxin treatment, in a time- and dose-dependent manner, elicits hypoglycemia and decreases the activity of hepatic gluconeogenic enzymes, particularly phosphoenolpyruvate carboxykinase (PEPCK), ${ }^{1}$ the rate-limiting enzyme in gluconeogenesis (2-5). As expected, decreased hepatic PEPCK enzyme activity in endotoxin-poisoned animals is accompanied by decreased gluconeogenesis $(2,6)$.

PEPCK plays a pivotal role in intermediary carbohydrate metabolism and the complex multihormonal control of the PEPCK gene reflects the importance of this enzyme in hepatic glucose production (7). Glucagon, via cAMP, and glucocorticoids (to a lesser extent) positively regulate PEPCK primarily by increasing the transcription rate of the gene $(8,9)$ and by stabilizing mRNA ${ }^{\text {PEPCK }}$ (mRNA coding for PEPCK) $(10,11)$. Conversely, insulin negatively regulates PEPCK by decreasing the transcription rate of the gene (12), an effect that is dominant over the inductive effect of cAMP and glucocorticoids in cell culture when all three hormones are present (13). Because all three hormones are present in vivo, the insulin/glucagon $(\mathrm{I} / \mathrm{G})$ molar ratio serves as an index of the metabolic status or gluconeogenic potential of the animal $(14,15)$. Endotoxin treatment of rats and mice results in increased plasma levels of glucagon, glucocorticoids, and insulin $(16,17)$, resulting in a very complex hormonal milieu. The hormonal status of endotoxin-treated animals is further complicated by the appearance in the circulation of inflammatory cytokines such as IL-1, TNF, and IL-6 (18). Human recombinant IL-1 and TNF, as well as purified murine IL-6, have been shown to decrease PEPCK enzyme activity in Reuber hepatoma cells $(19,20)$, but few studies have been conducted to examine the effect of cytokines on the regulation of PEPCK gene expression in vivo (21).

The purpose of this study, therefore, was to determine if the endotoxin-mediated decrease in PEPCK enzyme activity reported previously is due to decreased transcription of the PEPCK gene and if the putative decrease in PEPCK gene transcription is mediated solely by insulin. Our eventual goal is to determine how inflammatory cytokines interact with endocrine hormones (glucagon, glucocorticoids, and insulin) to regulate the hepatic PEPCK gene and gluconeogenesis during acute infection and inflammation.

\section{Methods}

Animals. Male, Sprague-Dawley rats (100-125 g) were purchased from Sasco (Omaha, NE). Animals were housed and cared for under the National Institutes of Health (NIH) guidelines for the care and use of laboratory animals. In some experiments, rats were treated with streptozotocin (Sigma Chemical Co., St. Louis, MO) to induce diabetes. After an overnight fast, rats were treated with $90 \mathrm{mg} / \mathrm{kg}$ of streptozotocin. $5 \mathrm{~h}$ later, food was returned to the cages and the animals were tested

1. Abbreviations used in this paper: I/G, insulin/glucagon; PEPCK, cytosolic phosphoenolpyruvate carboxykinase (GTP) (EC 4.1.32). 
7 to $10 \mathrm{~d}$ later for plasma glucose levels. Animals were considered diabetic and included in the study if their plasma glucose values were $>500 \mathrm{mg} / \mathrm{dl}$. All experimental protocols were approved by the Institutional Animal Care and Utilization Committee (IACUC) at the University of Oklahoma Health Sciences Center.

Endotoxin and IL-6. Endotoxin was prepared from Escherichia coli serotype 0111:B4 by the Westphal method (22) and was essentially protein and RNA free. The $\mathrm{LD}_{50}$ of this preparation, in Sprague-Dawley rats, was $35.5 \mathrm{mg} / \mathrm{kg}$ as determined by the Reed-Muench method (23). No deaths were observed during the course of the experiments described below, using a dose of $10 \mathrm{mg} / \mathrm{kg}$. Recombinant human IL-6 was purchased from Boehringer-Mannheim Biochemicals (Indianapolis, IN). The specific activity of IL-6 was greater than $2 \times 10^{8} \mathrm{U} / \mathrm{mg}$, as determined by stimulation of 7TD1 mouse-mouse hybridoma cells (24).

Nuclear run-on assay. The transcription elongation assay was carried out according to the procedure of Sasaki et al. (13), which was modified from the method of McKnight and Palmiter (25). After homogenization of liver tissue, nuclei were isolated through a series of centrifugations in sucrose buffers. Isolated nuclei $(200 \mu \mathrm{g})$ were incubated at $26^{\circ} \mathrm{C}$ for $10 \mathrm{~min}$ in $75 \mathrm{mM}$ HEPES at pH $8.0,100 \mathrm{mM} \mathrm{KCl}$, $2.5 \mathrm{mM} \mathrm{MgCl}_{2}, 25 \%$ glycerol, $0.1 \mathrm{mM}$ PMSF, $0.05 \mathrm{mM}$ EDTA, $4 \mathrm{mM}$ DTT, $25 \mathrm{U}$ RNasin, $0.5 \mathrm{mM}$ each of ATP, CTP, and GTP, and $200 \mu \mathrm{Ci}$ of $\left.\alpha-{ }^{32} \mathrm{P}\right]$ UTP $(400-600 \mathrm{Ci} / \mathrm{mmol})$. The reaction was terminated by digestion with DNAseI and proteinase $\mathrm{K}$ and after phenol extraction and alcohol precipitation, the RNA samples were hybridized with nitrocellulose-bound pPC112.R3 (provided by Dr. Daryl Granner, Vanderbilt University, Nashville, TN) or pBR322 as control. pPC112.R3 is a plasmid with a 5.8-kb EcoRI fragment of genomic PEPCK DNA inserted into the EcoRI site of pPR322 (26). All of the insert represents PEPCK DNA that is transcribed into precursor mRNA. The results are expressed as parts of PEPCK mRNA transcribed per one million parts of total RNA transcribed.

Quantitation of $m R N A$. After experimental treatment, total liver RNA was isolated by the Chirgwin method (27). RNA samples were denatured in $20 \times$ standard saline citrate plus $37 \%$ formaldehyde. After heating at $60^{\circ} \mathrm{C}$ for $15 \mathrm{~min}, 2.5 \mu \mathrm{l}$ of each sample were applied under vacuum to a nylon membrane with an $\mathrm{ABN}$ slot blot apparatus (American Bionetics, Hayward, CA). The blots were air dried and baked at $80^{\circ} \mathrm{C}$ for $1 \mathrm{~h}$. The blots were prehybridized for $6-18 \mathrm{~h}$ and hybridized overnight with a cDNA probe for PEPCK (pPC116, supplied by Dr. Daryl Granner) (26) or actin (Drosophila melanogaster, obtained from Dr. Sally Tobin, University of Oklahoma Health Sciences Center) labeled with ${ }^{32}[\mathrm{P}] \mathrm{dCTP}$ by random priming using the Amersham PrimeA-Gene kit (Amersham Corp, Arlington Heights, IL). The blots were washed under stringent conditions and autoradiographed. Intensity of bands was determined by laser scan densitometry and expressed as relative integrator units adjusted according to the $O D_{260}$ of the RNA samples. Northern analysis confirmed that the results obtained with the slot blot methodology were due to specific hybridization of mRNA $^{\text {PEPCK }}$ with PC116 (data not shown).

Biochemical assays. PEPCK enzyme activity was measured by the ${ }^{14} \mathrm{C}$-radiometric method of Chang and Lane (28) as described previously (2). Units of enzyme activity correspond to nanomoles of oxaloacetate formed from phosphoenolpyruvate per $15 \mathrm{~min}$ per $\mathrm{mg}$ of cytosol protein. Protein was quantitated using the BCA protein assay kit (29) from Pierce Chemical Co. (Rockford, IL). Plasma glucagon and insulin levels were measured using radioimmunoassay kits from Ventrex Laboratories (Cambridge, MA) and plasma corticosterone levels were measured using a radioimmunoassay kit from ICN Bio Medicals, Inc. (Costa Mesa, CA). Plasma glucose levels were measured using a colorimetric glucose oxidase assay kit from Sigma Chemical Co.

Induction of PEPCK gene transcription in vivo. There are primarily two ways to increase the transcription rate of the PEPCK gene in animals. The simplest method is by fasting overnight, which lowers the insulin/glucagon (I/G) molar ratio and results in an approximately twofold induction in the rate of transcription. Another method is by dietary manipulation which involves submitting the animal to a fast- ing-refeeding cycle followed by injection with cAMP (30). This experimental protocol, described originally by Iynedjian et al. (30), was used to manipulate the hormonal response in rats so that changes in the PEPCK transcription rate could be examined after endotoxin treatment. Briefly, animals were fasted overnight, refed with glucose $(0.5 \mathrm{~g})$ by gavage, and $2 \mathrm{~h}$ later dibutyryl cAMP $(30 \mathrm{mg} / \mathrm{kg})$ and theophylline $(30 \mathrm{mg} / \mathrm{kg})$ were administered intraperitoneally. Animals received dibutyryl-cAMP and theophylline (referred to hence as cAMP) every 90 min thereafter. Glucose feeding stimulates insulin release, which deinduces PEPCK gene expression $(31,32)$. Any increase in the PEPCK transcription rate can, therefore, be observed after administration of inducer (cAMP) (30, 32-33). The advantage of dietary manipulation over fasting is that the induction of PEPCK gene transcription is rapid and large. We have used both methods in the results described below.

Statistics. Statistical analysis of the data was performed by using Student's $t$ test (34).

\section{Results}

Effect of endotoxin on PEPCK gene expression. Previous work has shown that endotoxin treatment decreases PEPCK enzyme activity in mice 4 to $6 \mathrm{~h}$ after challenge $(35,36)$. The effect of endotoxin on transcriptional regulation of the PEPCK gene, however, has not been examined directly. Changes in PEPCK gene expression and circulating levels of insulin, glucagon, and corticosterone were assessed, therefore, in fasted rats $5 \mathrm{~h}$ after endotoxin treatment $(10 \mathrm{mg} / \mathrm{kg})$ (Table I). Endotoxin treatment significantly decreased the PEPCK transcription rate and amount of mRNA ${ }^{\text {PEPCK }}$ to approximately one-third of control. No change in mRNA actin was observed (data not shown). As expected, the hormonal status of endotoxin-treated animals was significantly altered, as indicated by a ninefold increase in the $\mathrm{I} / \mathrm{G}$ molar ratio and a fourfold increase in plasma corticosterone levels, compared with saline-treated controls. In rats given endotoxin, insulin values rose 18 -fold (control $=2.4 \pm 0.7 \mu \mathrm{U} /$ $\mathrm{ml}$ vs. endotoxin $=44.0 \pm 3.4 \mu \mathrm{U} / \mathrm{ml}$ ) and glucagon values doubled (control $=1,352 \pm 97 \mathrm{pg} / \mathrm{ml}$ vs. endotoxin $=2,734 \pm 251$ $\mathrm{pg} / \mathrm{ml}$ ). Similar changes in the PEPCK transcription rate were observed in rats given free access to food and treated with saline or endotoxin (control $=2,437 \mathrm{ppm}$ vs. endotoxin $=1,355$ ppm, $n=2$ ).

Altered cAMP induction of PEPCK gene expression after endotoxin treatment. To examine further the mechanism of altered PEPCK gene expression in endotoxic animals, the effect of endotoxin treatment on cAMP induction of PEPCK was tested. Endotoxin was injected $2 \mathrm{~h}$ before cAMP treatment because it has been demonstrated that serum levels of many inflammatory cytokines appear and/or peak $2 \mathrm{~h}$ after endo-

Table I. Endotoxin Action in Fasted Rats

\begin{tabular}{lcccc}
\hline $\begin{array}{c}\text { Treatment* } \\
(5 \mathrm{~h})\end{array}$ & $\begin{array}{c}\text { PEPCK } \\
\text { Transcription } \\
\text { rate }\end{array}$ & $\begin{array}{c}\mathrm{mRNA}^{\text {PEPCK }} \\
\text { (relative } \\
\text { integrator units) }\end{array}$ & $\begin{array}{c}\text { I/G molar } \\
\text { ratio }\end{array}$ & $\begin{array}{c}\text { Plasma } \\
\text { corticosterone }\end{array}$ \\
\hline & $p p m$ & & & $\mu g / d l$ \\
Controls & $3572 \pm 100^{\ddagger}$ & $201 \pm 26$ & $0.042 \pm 0.014$ & $15.6 \pm 2.0$ \\
Endotoxin & $1145 \pm 270^{\S}$ & $66 \pm 14^{\S}$ & $0.381 \pm 0.024^{\S}$ & $65.9 \pm 8.2^{\S}$
\end{tabular}

* Rats were fasted overnight, followed by an intraperitoneal injection of either $0.5 \mathrm{ml}$ of sterile saline or $E$. coli endotoxin $(10 \mathrm{mg} / \mathrm{kg})$. ${ }^{\ddagger}$ Mean value \pm SEM, $n=4 .{ }^{8}$ Statistically different from control $(P$ $<0.05$ ), determined by Student's $t$ test. 


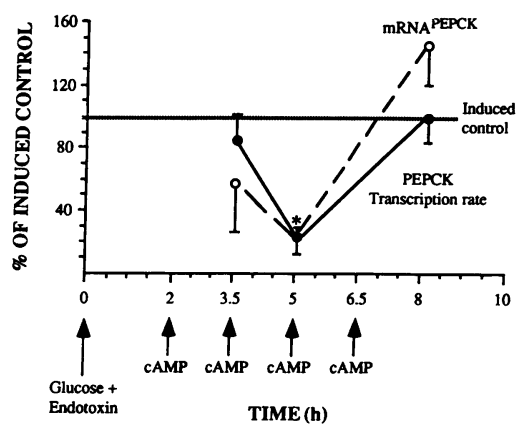

intraperitoneally with andline $(30 \mathrm{mg} / \mathrm{kg})$. Rats were treated with endotoxin $(10 \mathrm{mg} / \mathrm{kg}$ i.p.) at $0 \mathrm{~h}$ (simultaneously with glucose) and were killed at the indicated times. Nuclei and total RNA were isolated from the livers and were assayed for PEPCK transcription rates and $\mathrm{mRNA}^{\mathrm{PEPCK}}$ levels, as described under Methods. Results are expressed as the mean value \pm SEM and plotted as a percentage of induced control. Each time point represents data from four to six animals. Closed circles represent the PEPCK transcription rate and open circles represent $m \mathrm{mNA}^{\text {PEPCK}}$. *Values significantly different from induced controls $(P<0.05)$, as determined by Student's $t$ test.

toxin administration (18). The results are presented as a percentage of induced control due to variation from experiment to experiment. As can be seen in Fig. 1, a dynamic response to endotoxin was observed over the course of $8 \mathrm{~h}$. By $3.5 \mathrm{~h}$ after endotoxin treatment, no significant change in the PEPCK transcription rate or $\mathrm{mRNA}^{\mathrm{PEPCK}}$ level was observed in endotoxin plus cAMP-treated animals compared with induced controls. Significant inhibition of the PEPCK transcription rate and mRNA $^{\text {PEPCK }}$ level by endotoxin treatment, however, was observed at $5 \mathrm{~h}$ (control $=2,833 \pm 794 \mathrm{ppm}$ vs. endotoxin $=644 \pm 24 \mathrm{ppm}, P<0.05$ ). At $8 \mathrm{~h}$, PEPCK gene expression was not different from the induced controls. PEPCK enzyme activity was also significantly decreased in the endotoxin-treated group, compared with the induced controls at the 5-h time point. PEPCK enzyme activity was increased over deinduced controls (animals receiving glucose only) by $262 \mathrm{U} / \mathrm{mg}$ compared with $134 \mathrm{U} / \mathrm{mg}$ in endotoxic animals $(51 \%$ of induced controls, $P<0.05) .6 \mathrm{~h}$ after cAMP treatment $(8 \mathrm{~h}$ after endotoxin), PEPCK enzyme activity was not significantly different from induced controls.

The plasma profiles of insulin, glucagon, and the I/G molar ratio, in control and endotoxic animals subjected to fasting-refeeding and cAMP injection, are illustrated in Fig. 2. Endotoxin treatment significantly increased insulin levels after 3.5 and $5 \mathrm{~h}$, however, by $8 \mathrm{~h}$, the insulin values in control and endotoxic rats were similar. In contrast to the insulin response, glucagon levels were increased by $2 \mathrm{~h}$ after endotoxin treatment and remained elevated by $8 \mathrm{~h}$. At 3.5 and $5 \mathrm{~h}$, the I/G molar ratio was increased in endotoxic animals (although not statistically different from induced controls at $5 \mathrm{~h}$ ), yet by $8 \mathrm{~h}$ the I/G molar ratio was similar to the induced controls. The increased insulin levels and the I/G molar ratio correlated well with decreased PEPCK gene expression in endotoxin-treated animals and suggested a role for insulin in downregulation of PEPCK gene expression during endotoxemia.

PEPCK gene expression in diabetic rats after endotoxin treatment. In order to examine further the role of insulin in the downregulation of PEPCK gene expression during endotoxe-

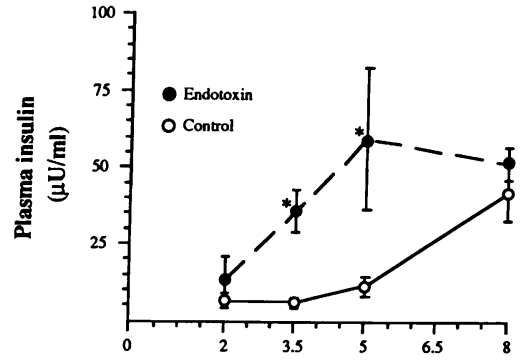

Figure 2. Time course of insulin, glucagon, and $\mathrm{I} / \mathrm{G}$ molar ratio in endotoxin-treated rats after glucose feeding

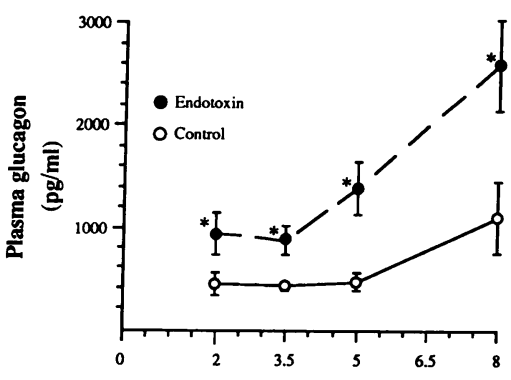
and induction of PEPCK with dibutyrylcAMP treatment. Rats were treated as described in the legend to Fig. 1. Plasma was collected for determination of glucagon and insulin levels by radioimmunoassay as described under Methods. Results are expressed as the mean

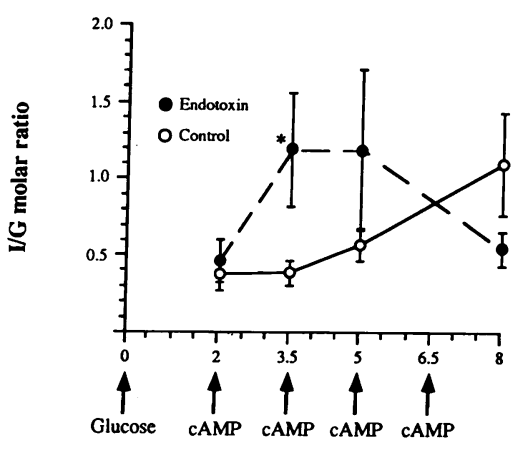

TIME (h) value \pm SEM. Each time point represents data from four to six animals. Open circles represent saline treated animals and closed circles represent endotoxin treated animals. *Values significantly different from induced controls $(P<0.05)$, as determined by Student's $t$ test.

mia, diabetic (plasma glucose $>500 \mathrm{mg} / \mathrm{dl}$ ) rats were fasted overnight, treated with sterile saline or endotoxin $(10 \mathrm{mg} / \mathrm{kg})$, and killed $5 \mathrm{~h}$ later. PEPCK gene expression and circulating hormone levels were examined. The results are shown in Table II. In the diabetic rats, endotoxin treatment resulted in a significant decrease in the PEPCK transcription rate and mRNA $^{\text {PEPCK }}$ to at least one-third of the values obtained from diabetic rats given saline. Plasma corticosterone levels in diabetic rats receiving endotoxin were significantly elevated compared with diabetic controls and were similar to the levels observed in the nondiabetic animals given endotoxin. A signifcant decrease in PEPCK gene expression occurred in diabetic animals, however, in the absence of increased plasma levels of insulin or glucagon. In diabetic rats given endotoxin, there was no significant change in insulin values (control $=3.3 \pm 1.5 \mu \mathrm{U}$ / $\mathrm{ml}$ vs. endotoxin $=3.7 \pm 3.7 \mu \mathrm{U} / \mathrm{ml}$ ) or glucagon values (control $=2,539 \pm 729 \mathrm{pg} / \mathrm{ml}$ vs. endotoxin $=2,786 \pm 653 \mathrm{pg} / \mathrm{ml}$ ). Thus, PEPCK was downregulated despite no change in the $\mathrm{I} / \mathrm{G}$ molar ratio.

Altered CAMP induction of PEPCK gene expression after $I L-6$ treatment. Based on the observation in diabetic rats, that insulin alone did not decrease PEPCK gene expression during endotoxemia, we investigated the role of human recombinant IL-6 in the regulation of PEPCK gene expression. IL-6 modulates the expression of many hepatic acute phase genes during acute infection and inflammation and may serve as a second signal of IL-1 and TNF during endotoxemia (18). When fasted 
Table II. Endotoxin Action in Diabetic Rats

\begin{tabular}{lcccc}
\hline $\begin{array}{c}\text { Treatment* } \\
(5 \mathrm{~h})\end{array}$ & $\begin{array}{c}\text { PEPCK } \\
\text { Transcription } \\
\text { rate }\end{array}$ & $\begin{array}{c}\mathrm{mRNA}^{\text {PEPCK }} \\
\text { (relative } \\
\text { integrator units) }\end{array}$ & $\begin{array}{c}\text { I/G molar } \\
\text { ratio }\end{array}$ & $\begin{array}{c}\text { Plasma } \\
\text { cortico- } \\
\text { sterone }\end{array}$ \\
\hline & $p p m$ & & & $\mu g / d l$ \\
$\begin{array}{l}\text { Diabetic controls } \\
\text { Diabetic } \\
+ \text { endotoxin }\end{array}$ & $2580 \pm 39^{\ddagger}$ & $468 \pm 70$ & $0.029 \pm 0.007$ & $32.3 \pm 2.5$ \\
& $956 \pm 134^{\S}$ & $249 \pm 51^{\S}$ & $0.025 \pm 0.01$ & $65.3 \pm 3.2^{\S}$
\end{tabular}

* Rats were fasted overnight, followed by an intraperitoneal injection of either $0.5 \mathrm{ml}$ of sterile saline or $E$. coli endotoxin $(10 \mathrm{mg} / \mathrm{kg})$. ${ }^{\ddagger}$ Mean value \pm SEM, $n=4 .{ }^{8}$ Statistically different from control $(P$ $<0.05$ ), determined by Student's $t$ test.

rats were injected with human recombinant IL-6 (10,000 U) and killed $5 \mathrm{~h}$ later, there was no change, compared with saline injected controls, in any of the parameters of PEPCK gene expression (PEPCK transcription rate, mRNA ${ }^{\text {PEPCK}}$, or PEPCK enzyme activity), the I/G molar ratio, or plasma glucose levels (data not shown). Plasma corticosterone values, however, were elevated threefold (control $=15.6 \pm 2.0 \mu \mathrm{g} / \mathrm{dl}$ vs. IL-6 $=51.1 \pm 9.4 \mu \mathrm{g} / \mathrm{dl}, P<0.05)$. Because glucocorticoids alone can increase PEPCK gene expression (8), we tested whether IL-6, via increased corticosterone levels, could enhance the CAMP induction of PEPCK gene expression, using the experimental protocol described in the legend to Fig. 1. Animals were treated with IL-6 (10,000 U) simultaneously with glucose and killed $5 \mathrm{~h}$ later (after $3 \mathrm{~h}$ of cAMP treatment). Interestingly, IL-6 treatment resulted in a significant decrease in the PEPCK transcription rate and RRNA $^{\text {PEPCK }}$ levels, compared with induced controls (Table III). No significant change in PEPCK enzyme activity was observed, however, in the IL-6treated animals, compared with induced controls (induced controls $=262 \pm 13 \mathrm{U} / \mathrm{mg}$ vs. IL- $6=214 \pm 21 \mathrm{U} / \mathrm{mg}$ ). In addition, no significant change occurred in the $I / G$ molar ratio, compared with the induced controls.

\section{Discussion}

The molecular mechanisms involved in decreased gluconeogenesis after endotoxin treatment have not been fully elucidated. The data presented here demonstrate that the previously observed decrease in PEPCK enzyme activity after endotoxin

Table III. Effect of IL-6 Treatment on cAMP Induction of PEPCK Gene Expression

\begin{tabular}{lccc}
\hline Treatment* & $\begin{array}{c}\text { PEPCK } \\
\text { Transcription } \\
\text { rate }\end{array}$ & $\begin{array}{c}\text { mRNA } \\
\text { (relative integrator } \\
\text { units) }\end{array}$ & $\begin{array}{c}\text { I/G molar } \\
\text { ratio }\end{array}$ \\
\hline Control & $2833 \pm 797^{\ddagger}$ & $149.1 \pm 12.1$ & \\
IL-6 & $344 \pm 127^{\S}$ & $87.2 \pm 9.6^{\S}$ & $0.59 \pm 0.17$ \\
& & & $0.82 \pm 0.15$
\end{tabular}

* Rats were treated as described in the legend to Fig. 1, except that IL-6 $(10,000 \mathrm{U})$ was injected instead of endotoxin and the animals were killed at the 5-h time point. ${ }^{\ddagger}$ Mean value \pm SEM, $n=4$. ${ }^{5}$ Statistically different from control $(P<0.05)$, determined by Student's $t$ test. treatment results from decreased gene expression. With the recent availability of appropriate cDNA probes (7), we were able to demonstrate, in endotoxic animals, a decrease in the PEPCK transcription rate, which was reflected subsequently in a decreased amount of $m R N A^{\text {PEPCK }}$. After endotoxin treatment, the magnitude of change in $\mathrm{mRNA}^{\text {PEPCK }}$ corresponded well with the magnitude of change in the transcription rate, suggesting that the decrease in $\mathrm{mRNA}^{\mathrm{PEPCK}}$ was due to a corresponding decrease in the PEPCK transcription rate. It is interesting to note that decreased PEPCK gene expression was observed in this study in endotoxic rats that were $(a)$ fasted overnight and during the experiment, $(b)$ fed (allowed access to food), or $(c)$ fasted overnight, refed with glucose, and treated with CAMP. Considering the dominant role of insulin in downregulating the PEPCK gene (7), the observed elevation in the I/G molar ratio could account for the decrease in PEPCK gene expression during endotoxemia. In order to determine if insulin was the only hormone downregulating PEPCK gene expression during endotoxemia, we used diabetic rats that were hyperglycemic and had low, but detectable, levels of plasma insulin. Using a nonlethal dose of endotoxin in diabetic rats, we demonstrated that decreased PEPCK gene expression occurred in the absence of an increase in plasma insulin. It is interesting to note that plasma glucagon levels were elevated to a similar degree in control and endotoxin-treated diabetic rats (which was twice the value observed in normal fasted rats), yet the observed hyperglucagonemia failed to prevent the decrease in PEPCK gene expression due to endotoxin. These results support previous reports that, in addition to glucocorticoids, PEPCK is nonresponsive to regulation by glucagon in endotoxic animals (16). These results further suggest that other factors, in addition to insulin, may be involved in the negative regulation of PEPCK during acute infection or inflammation.

It has been well documented that the effect of endotoxin to inhibit hepatic gluconeogenesis and PEPCK is not a direct effect of endotoxin on the liver $(1,2,6,37)$. IL-1, TNF, and IL-6 have been implicated as mediators of the endotoxin effect on PEPCK because they decrease enzyme activity and $\mathrm{mRNA}^{\text {PEPCK }}$ in vitro in Reuber H-4-II-E rat hepatoma cells $(19,20,38)$. Multiple cytokines appear in the circulation after endotoxin treatment and may elicit the production of additional cytokines, resulting in a cascade of inflammatory mediators (18). We chose to examine IL-6 as a putative mediator of endotoxin action on PEPCK gene expression because IL- 6 is the dominant cytokine involved in induction of the hepatic acute phase proteins (39-41) and because endotoxin, TNF, and IL- 1 elicit IL-6 production $(42,43)$. IL-6 acts via a specific membrane receptor (44) and after binding there is increased transcription of hepatic acute phase genes, such as $\alpha_{2}$-macroglobulin, haptoglobin, cysteine proteinase inhibitor, and $\alpha_{1}$ acid glycoprotein. Concomitantly, synthesis of several acute phase proteins, such as albumin, is decreased after treatment with IL-6 (39-41). The dose of IL-6 (10,000 U/100 g rat) used in these studies was chosen based on a previous study by Marinkovic et al. (45) who reported that $40,000 \mathrm{U}$ IL- 6 per $400 \mathrm{~g}$ rat were necessary to elicit the same acute phase response quantitatively as an acute inflammatory agent, turpentine.

The results we obtained with IL-6 treatment are interesting, but somewhat perplexing. IL- 6 treatment, after $5 \mathrm{~h}$, had no effect on PEPCK gene expression in fasted rats, indicating that the cytokine alone, at the indicated dose, is not capable of mediating the endotoxin effect on PEPCK gene expression. IL-6 
treatment, however, decreased the PEPCK transcription rate and the amount of $\mathrm{mRNA}^{\text {PEPCK }}$ after cAMP treatment in fasted, refed rats. The magnitude of decrease in the PEPCK transcription rate was much greater than the observed decrease in mRNA $^{\text {PEPCK}}$, which suggests that increased stabilization of mRNA ${ }^{\text {PEPCK }}$ may have occurred. Although glucocorticoids have been shown to stabilize $\mathrm{mRNA}^{\text {PEPCK }}$ in Reuber hepatoma cells (11), it is not known if the observed increase in corticosterone levels after IL-6 treatment contributed to increased mRNA $^{\text {PEPCK }}$ stabilization. The observation that no significant change in PEPCK enzyme activity occurred in the IL-6-treated animals lends support to this idea. One explanation for the IL-6 inhibition of cAMP-mediated induction of PEPCK gene expression might be that IL-6 acts as an insulin-like factor (46) or that the cytokine prolongs the action of insulin when it is administered at the same time as glucose. Other investigators have reported that IL-6 enhances glucose-stimulated production of insulin from isolated pancreatic $\beta$-cells (47), however, we observed no change in insulin levels after IL-6 treatment. Although an IL-6 response element has not been mapped on the promoter region of the PEPCK gene, a core hexanucleotide CTGGGA sequence found in the promoter region of IL-6 responsive genes, is found in the 5 '-flanking region of the PEPCK gene described as the glucocorticoid response unit (GRU) (48). A portion of the GRU also overlaps with the recently described insulin response element (IRE) (49). This raises the possibility, although purely speculative, that putative nuclear elements or factors mediating the IL-6 effect on the PEPCK gene, under certain conditions, interact at the GRU, IRE, or the cAMP response element.

Although insulin decreases PEPCK synthesis after the appropriate dietary stimulus in normal animals, it is clear from our results that other factors in addition to insulin contribute to the negative regulation of the PEPCK gene during endotoxemia. We observed in this study that endotoxin elicited a transient change in PEPCK gene expression, however, the change occurred at a critical time in the development of progressive hypoglycemia (2). When larger doses of endotoxin $\left(L D_{50}\right)$ are administered, PEPCK enzyme activity is significantly decreased at a time coincident with developing hypoglycemia (4$6 \mathrm{~h}$ ) and remains depressed throughout the course of the experiment (2). Although decreased PEPCK enzyme activity is not solely responsible for the observed hypoglycemia in septic animals, it is an important factor in the failure of the gluconeogenic pathway to provide sufficient glucose to satisfy the increased energy demands of the injured host. Further studies are required to identify putative inflammatory mediators involved and to elucidate how they interact with insulin in negatively regulating PEPCK gene expression during acute infection and inflammation.

\section{Acknowledgments}

We gratefully acknowledge the assistance of Dr. Daryl Granner for allowing one of the authors (Dr. Hill) to spend valuable time in his laboratory studying the transcriptional regulation of PEPCK and for providing the necessary cDNA probes to carry out these studies. The enlightening discussions of Dr. Richard Printz are greatly appreciated. The expert technical assistance of Brad King is also gratefully acknowledged. The authors thank Dr. Robert Steinberg (Department of Biochemistry, University of Oklahoma Health Sciences Center) for the use of the laser densitometer, which was purchased with funds provided by the Oklahoma Center for Advancement of Science and Technology (OCAST) and Presbyterian Health Foundation.

We would also like to thank OCAST and Presbyterian Health Foundation for supporting this work.

\section{References}

1. McCallum, R. E. 1975. Carbohydrate metabolism in experimental endotoxemia. In Gram-Negative Bacterial Infections. Pathophysiological, Immunological, and Clinical Aspects. Springer-Verlag, New York. 281-287.

2. McCallum, R. E., and L. J. Berry. 1973. Effects of endotoxin on gluconeogenesis, glycogen synthesis, and liver glycogen synthase in mice. Infect. Immunol. 7:642-654.

3. Rippe, D. F., and L. J. Berry. 1972. Study of inhibition of induction of phosphoenolpyruvate carboxykinase by endotoxin with radial immunodiffusion. Infect. Immunol. 6:766-772.

4. Smith, S. M., and I. S. Snyder. 1975. Effect of lipopolysaccharide and lipid A on mouse liver pyruvate kinase activity. Infect. Immunol. 12:993-998.

5. Berry, L. J., D. S. Smythe, and L. S. Colwell. 1968. Inhibition of hepatic enzyme induction as a sensitive assay for endotoxin. J. Bacteriol. 96:1191-1199.

6. McCallum, R. E. 1980. Mediated inhibition of hepatic gluconeogenesis by endotoxin. In Microbiology. American Society Microbiology, Washington, DC 87-90.

7. Granner, D. K. 1987. The molecular biology of insulin action on protein synthesis. Kidney Int. 32:S82-S93.

8. Gunn, J., R. Hanson, O. Meyuhas, L. Reshef, and J. Ballard. 1975. Glucocorticoids and the regulation of phosphoenolpyruvate carboxykinase (guanosine triphosphate) in the rat. Biochem. J. 150:195-203.

9. Gunn, J. M., S. M. Tilghman, R. W. Hanson, L. Reshef, and F. J. Ballard. 1975. Effects of cyclic adenosine monophosphate, dexamethasone, and insulin on phosphoenolpyruvate carboxykinase synthesis in Reuber H-35 hepatoma cells. Biochemistry. 14:2350-2357.

10. Hod, Y., and R. W. Hanson. 1988. Cyclic AMP stabilizes the mRNA for phosphoenolpyruvate carboxykinase (GTP) against degradation. J. Biol. Chem. 263:7747-7752.

11. Petersen, D. D., S. R. Koch, and D. K. Granner. 1989. 3' noncoding region of phosphoenolpyruvate carboxykinase mRNA contains a glucocorticoid-responsive mRNA-stabilizing element. Proc. Natl. Acad. Sci. USA. 86:7800-7804.

12. Granner, D. K., T. L. Andreone, K. Sasaki, and E. Beale. 1983. Inhibition of transcription of the phosphoenolpyruvate carboxykinase gene by insulin. $\mathrm{Na}$ ture (Lond.). 305:545-549.

13. Sasaki, K., T. P. Cripe, S. R. Koch, T. L. Andreone, D. D. Petersen, E. G. Beale, and D. K. Granner. 1984. Multihormonal regulation of phosphoenolpyruvate carboxykinase gene transcription. J. Biol. Chem. 259:15242-15251.

14. Exton, J. H. 1972. Gluconeogenesis. Metab. Clin. Exp. 21:945-990.

15. Granner, D., and S. Pilkis. 1990. The genes of hepatic glucose metabolism. J. Biol. Chem. 265:10173-10176.

16. Stith, R. D., and R. E. McCallum. 1988. Failure of glucagon to induce hepatic phosphoenolpyruvate carboxykinase in endotoxic shock. Circ. Shock. 26:267-272.

17. Kelleher, D. L., G. J. Bagby, and J. J. Spitzer. 1981. Metabolic and endocrine alterations following endotoxin administration in normal and diabetic rats. In Homeostasis in Injury and Shock. Advances in Physiological Sciences. Pergamon Press, Inc., New York. 181-189.

18. Akira, S., T. Hirano, T. Taga, and T. Kishimoto. 1990. Biology of multifunctional cytokines: IL-6 and related molecules (IL-1 and TNF). FASEB (Fed. Am. Soc. Exp. Biol.) J. 4:2860-2867.

19. McCallum, R. E., M. R. Hill, and R. D. Stith. 1988. Inhibited steroid induction of PEPCK in hepatoma cells treated with HurIL-1 and HurTNF. In Monokines and Other Non-Lymphocytic Cytokines. Alan R. Liss, Inc., New York. 267-272.

20. Hill, M. R., R. D. Stith, and R. E. McCallum. 1989. Mechanism of action of interferon- $\beta_{2} /$ interleukin- 6 on induction of hepatic liver enzymes. Ann. $N Y$ Acad. Sci. 557:502-505.

21. Hill, M. R., R. D. Stith, and R. E. McCallum. 1986. Interleukin-1: a regulatory role in glucocorticoid-regulated hepatic metabolism. J. Immunol. 137:858-862.

22. Westphal, O., and K. Jann. 1965. Bacterial lipopolysaccharides: extraction with phenol-water and further applications of the procedure. Methods Carbohydr. Chem. 5:83-94.

23. Reed, L. J., and H. A. Muench. 1938. A simple method for estimating 50\% end points. Am. J. Hyg. 27:493-499.

24. Van Snick, J., S. Cayphas, A. Vink, C. Uyttenhove, P. Coulie, and R. Simpson. 1986. Purification and $\mathrm{NH}_{2}$-terminal amino acid sequence of a new $\mathrm{T}$ cell-derived lymphokine with growth factor activity for B cell hybridomas. Proc. Natl. Acad. Sci. USA. 83:9679-9683.

25. McKnight, G. S., and R. D. Palmiter. 1979. Transcription regulation of 
the ovalbumin and conalbumin genes by steroid hormones in chick oviduct. $J$. Biol. Chem. 254:9050-9058.

26. Beale, E. G., N. B. Chrapkiewicz, H. Scoble, R. J. Metz, R. L. Noble, D. P. Quick, J. E. Donelson, K. Biemann, and D. K. Granner. 1985. Rat hepatic cytosolic phosphoenolpyruvate carboxykinase (GTP). Structures of the protein, messenger RNA, and gene. J. Biol. Chem. 260:10748-10760.

27. Chirgwin, J. M., A. E. Przybyla, R. J. MacDonald, and W. J. Rutter. 1979. Isolation of biologically active ribonucleic acid from sources enriched in ribonuclease. Biochemistry. 18:5294-5299.

28. Chang, H. C., and M. D. Lane. 1966. The enzymatic carboxylation of phosphoenolpyruvate. II. Purification and properties of liver phosphoenolpyruvate carboxykinase. J. Biol. Chem. 241:2413-2420.

29. Smith, P. K., R. I. Krohn, G. T. Hermanson, A. K. Mallia, F. H. Gartner, M. D. Provenzano, E. K. Fujimoto, N. M. Goeke, B. J. Olson, and D. C. Klenk. 1985. Measurement of protein using bicinchoninic acid. Anal. Biochem. 150:7685 .

30. Iynedjian, P., and R. Hanson. 1977. Increase in level of functional messenger RNA coding for phosphoenolpyruvate carboxykinase (GTP) during induction by cyclic adenosine 3':5'-monophosphate. J. Biol. Chem. 252:655-662.

31. Kioussis, D., L. Reshef, H. Cohen, S. M. Tilghmann, P. B. Iynedjian, F. J. Ballard, and R. W. Hanson. 1978. Alterations in translatable messenger RNA coding for phosphoenolpyruvate carboxykinase (GTP) in rat liver cytosol during deinduction. J. Biol. Chem. 253:4327-4332.

32. Beale, E. G., C. S. Katzen, and D. K. Granner. 1981. Regulation of rat liver phosphoenolpyruvate carboxykinase (GTP) messenger ribonucleic acid activity by $\mathrm{N}_{6}, \mathrm{O}_{2}^{\prime}$-dibutyryladenosine $3^{\prime}, 5^{\prime}$-phosphate. Biochemistry. 20:48784883 .

33. Beale, E. G., J. L. Hartley, and D. K. Granner. 1982. $\mathrm{N}_{6}, \mathrm{O}_{2}^{\prime}$-dibutyryl cyclic AMP and glucose regulate the amount of messenger RNA coding for hepatic phosphoenolpyruvate carboxykinase (GTP). J. Biol. Chem. 257:20222028.

34. Winer, B. J. 1971. Statistical Principles in Experimental Design. McGrawHill, New York.

35. McCallum, R. E., T. W. Seale, and R. D. Stith. 1983. Influence of endotoxin treatment on dexamethasone induction of hepatic phosphoenolpyruvate carboxykinase. Infect. Immunol. 39:213-219.

36. Berry, L. J., and W. B. Huff. 1984. Antiglucocorticoid effects of endotoxin. Circ. Shock. 14:137-145.
37. Hill, M. R., R. D. Stith, and R. E. McCallum. 1987. Monokines mediate decreased hepatic glucocorticoid binding in endotoxemia. J. Leukocyte Biol. 41:236-241.

38. Hill, M. R., R. D. Stith, and R. E. McCallum. 1988. Human recombinant IL-1 alters glucocorticoid receptor function in Reuber hepatoma cells. J. Immunol. 141:1522-1528.

39. Gauldie, J., and H. Baumann. 1990. Cytokines and acute phase protein expression. In Cytokines in Inflammation. E. Kimball, editor. CRC Press, Boca Roton, FL. In press.

40. Fey, G., and J. Gauldie. 1990. The acute phase response of the liver in inflammation. Prog. in Liver Dis. 9:89-116.

41. Baumann, H., and J. Gauldie. 1990. Regulation of hepatic acute phase plasma protein genes by hepatocyte stimulating factors and other mediators of inflammation. Mol. Biol. Med. 7:147-159.

42. Fong, Y., L. Moldawer, M. Marano, H. Wei, S. Tatter, R. Clarick, U. Santhanum, D. Sherris, L. May, P. Sehgal, and S. Lowry. 1989. Endotoxemia elicits increased circulating $\beta_{2}$-IFN/IL-6 in man. J. Immunol. 142:2321-2324.

43. Jablons, D. M. J. J. Mule, J. K. McIntosh, P. Sehgal, L. May, C. Huang S. Rosenberg, and M. Lotze. 1989. IL-6/IFN- $\beta_{2}$ as a circulating hormone. Induction by cytokine administration in humans. J. Immunol. 142:1542-1547.

44. Taga, T., Y. Kawanishi, R. R. Hardy, T. Hirano, and T. Kishimoto. 1987. Receptors for B cell stimulatory factor 2: quantitation, specificity, distribution and regulation of their expression. J. Exp. Med. 166:967-981.

45. Marinkovic, S., G. P. Jahreis, G. G. Wong, and H. Baumann. 1989. IL-6 modulates the synthesis of a specific set of acute phase plasma proteins in vivo. $J$. Immunol. 142:808-812.

46. Filkins, J. P. 1980. Endotoxin-enhanced secretion of a macrophage insulin-like activity. J. Reticuloendothel. Soc. 27:507-510.

47. Sandler, S., K. Bendtzen, D. L. Eizirik, and M. Welsh. 1990. Interleukin-6 affects insulin secretion and glucose metabolism of rat pancreatic islets in vitro. Endocrinology. 126:1288-1294.

48. Imai, E., P. Stromstedt, P. Quinn, J. Carlstedt-Duke, J. Gustafsson, and D. Granner. 1990. Characterization of a complex glucocorticoid response unit in the phosphoenolpyruvate carboxykinase gene. Mol. Cell. Biol. 10:4712-4719.

49. O'Brien, R. M., P. C. Lucas, C. D. Forest, M. A. Magnuson, and D. K. Granner. 1990. Identification of a sequence in the PEPCK gene that mediates a negative effect of insulin on transcription. Science (Wash. DC). 249:533-537. 